\title{
Joggyakorlat
}

\author{
Csatlós ERzsébet*
}

\section{Hajóroncsmentés mint beruházás - egy ICSID-döntés alapvető hatása két jogterületen}

\author{
hajóroncs - beruházásvédelem - ICSID - Diana - Malaysian Historical Salvors
}

Az elsüllyedt hajók, és főként azok rakománya időtlen idők óta vonzza a kincsvadászokat. Tévedés azonban, hogy az elsüllyedt hajók szabad prédává váltak volna; noha az irányadó jog is meglehetősen sokrétű és kaotikus, számos szempontot szükséges egyszerre figyelembe venni. Ez legfőképpen két érdek szembenállásában mutatkozik meg.

A hajóroncsok felkutatása és a rakományok felszínre hozása a technikai fejlődés eredményeképpen egyre gyakoribb. ${ }^{1}$ Nem hivatalos adatok szerint eddig 118300 víz alatti hajóroncsról tudunk, amelyböl 115 030-at lokalizáltak. ${ }^{2}$ A sokszor évszázadok óta hullámsírban fekvő hajók és rakományuk a történelem egy darabját jelentik, azok kulturális értéke felbecsülhetetlen, így számos állam érdekében áll a régészeti jellegü kincsek feltérképezése és megmentése. Ez viszont megfelelő technológiát, eszközöket és tetemes anyagi ráfordítást igényel, amellyel legtöbbször erre szakosodott, sokszor „kincsvadásznak” titulált szerveződések, társaságok rendelkeznek, amelyek elsősorban profitorientáltak, így a mentés és az értékesítés a céljuk, és nem pedig a régészeti jelleg megóvása, ahogy erre sokszor képesítésük sincs. A két fél azonban a kulturális érdekek megőrzése, és ezzel párhuzamosan a világ számára való megismerhetősége miatt együttmüködésre van ítélve, az azonban nem mindegy, hogy milyen feltételek mellett.

* Dr. Csatlós Erzsébet tudományos segédmunkatárs, SZTE ÁJTK, Nemzetközi Jogi és Európa-jogi Tanszék, csatlos.e@juris.u-szeged.hu.

1 Grenier, Robert Nutley-Cochran, Ian David: Underwater Cultural Heritage at Risk: Managing Natural and Human Impacts. ICOMOS-International Council on Monuments and Sites, Paris (2006) i.

2 A Wrecksite a hajóroncsokra vonatkozóan a világ legnagyobb online adatbázisa. http://www.wrecksite.eu/ Wrecksite.aspx (2013.05.06.) 
A parti államot a tengerjog szabályai szerint generális kötelezettség terheli a tengerben talált régészeti és történelmi jelentőségü tárgyak védelmét illetően. ${ }^{3}$ Számos esetben ez a védelem a kincsek felszínre hozatalát jelenti, és múzeumban való elhelyezésükben nyilvánul meg. Megoszlik a vélemény a tudósok körében, hogy ez vagy az in situ védelem szolgálja-e jobban a víz alatti kincsek mint a kulturális örökség megóvását, ${ }^{4}$ mindenesetre elterjedt gyakorlat, hogy a kiaknázással kifejezetten erre a tevékenységre specializálódott, a megfelelő tőkével, felszereléssel és szakértelemmel rendelkező társaságokat bíznak meg a feladat elvégzésére. Ezek a szerződések az évszázadokkal ezelőtt, a szokásjogban kialakult mentési jogon alapulnak, olyannyira, hogy formanyomtatványként is kezdenek elterjedni. A mentési jog eredetileg azokra az esetekre vonatkozott, amikor a tengeri veszélybe került vízi járművet és annak rakományát olyan személy menti meg a pusztulástól, akinek erre vonatkozóan jogi kötelezettsége nincs, és így a tevékenysége jutalmat érdemel. ${ }^{5}$ Ennek a modern verziója a kereskedelmi mentési szerződés, amely alapján a bajba jutott hajókat segítik, és ebből a jogviszonyból vezették le a történelmi mentési szerződéseket, amelyek a már akár több évtizede vagy évszázada a tengerfenéken nyugvó hajók és/vagy rakományuk felszínre hozatalára vonatkoznak. Fő jellemzője, hogy a mentést végző finanszírozza a kutatást, és vállalja annak kockázatát, hogy esetleg sikertelen a tevékenysége, és ebben az esetben a profit is elmarad. ${ }^{6}$

Az állam gyakran köt szerződést a mentéssel foglalkozó, igen gyakran külföldi érdekeltségű társasággal az adott tevékenység elvégzésére. Mi történik azonban, ha az állam és a tényleges felkutatási munkát végző személy érdekei ütköznek? Hol talál megfelelő jogi védelmet ez utóbbi egy állammal szemben? A Beruházási Viták Rendezésének Nemzetközi Központjánál (International Center of Settlement of Investment Disputes, ICSID) előtt zajlott, 2009-ben zárult Diana-ügy (ICSID ARB/05/10) új korszakot nyitott a hajóroncsok felkutatására irányadó jog tekintetében. Az abban eljáró választott bíróság ugyanis elismerte, hogy maga a tevékenység beruházásnak minősül, és emiatt a vonatkozó beruházásvédelmi egyezmények alkalmazhatóak, és az esetleges jogvita az államtól független nemzetközi fórum, az ICSID elé vihető.

A tanulmány célja megvizsgálni azt, hogy lehetséges-e, hogy a külföldi társaságok mentési szerződés alapján kifejtett tevékenysége számára védelmet nyújtson a beruházásvédelem körében kialakult független mechanizmus - az ICSID eljárása - a fogadó állammal szemben.

3 United Nations Convention on the Law of the Sea Montego Bay, 10 December 1982. 1833 U.N.T.S. 3. [a továbbiakban: UNCLOS] 303. cikk (1). Ez a cikk nem érinti az azonosítható tulajdonosok jogait, a tengeri mentés szabályait, illetve a kereskedelmi tengerészet más szabályait vagy a kulturális cserére vonatkozó törvényeket és gyakorlatokat. UNCLOS 303. cikk (3).

4 L. Mıglorino, Luigi: In Situ Protection of the Underwater Cultural Heritage under International Treaties and National Legislation. International Journal of Marine and Coastal Law, 10 (1995) 483-496.

5 Leigh Miller, Mariann: Underwater Cultural Heritage: Is the Titanic Still in Peril as Courts Battle over the Future of the Historical Vessel? Emory International Law Review, 20 (2006) 353.

6 Gold, Edgar: Marine Salvage: Towards a New Regime. Journal of Maritime Law and Commerce, 20 (1989) 4 487-488.

7 Malaysian Historical Salvors Sdn., Bhd. v. The Government of Malaysia (ICSID Case No. ARB/05/10) Decision on Anullment, April 16, 2009 [a továbbiakban Diana-ügy, a hivatkozásokban Diana-case]. 


\section{A Diana-ügy és a beruházásvédelem}

A Diana, a Kalkutta és Kanton között kereskedő, kínai porcelánnal megrakott brit hajó Indiából visszatérve 1817. március 17-én süllyedt el a Malaka-szorosban. A roncs lelöhelye a mai malajziai parti tenger alatt van.

A malajziai kormány 1991. augusztus 3-án szerződést kötött a zömmel brit részvényesekből álló, de maláj jog szerint bejegyzett, Malaysian Historical Salvors (Malajziai Történelmi Mentéssel Foglalkozó Társaság, MHS) elnevezésű társasággal. A megállapodás értelmében a társaság az állam számára saját költségén és eszközeivel, a szakértelmét felhasználva lokalizálja a roncsot és felszínre hozza annak rakományát, és vállalja a mentéssel felmerülő összes kockázatot, továbbá megtisztítja és katalogizálja az értéktárgyakat, és végül a Christie's nemzetközi aukciósház keretén belül intézkedik azok elárverezéséről. ${ }^{8}$

A szerződés a klasszikus „nincs kincs, nincs pénz" elv alapján állapította meg a fizetséget, vagyis a mentéssel megbízott társaság csak akkor profitál az elvégzett munkából, ha sikerül értékesíteni a felszínre hozott tárgyakat. A megállapodás szerint, ha az eladott és az el nem adott kincsek becsült értéke nem éri el a 10 millió amerikai dollárt, akkor a társaság az érték 70\%-ára jogosult, ha 10 és 20 millió amerikai dollár közötti, akkor $60 \%$-a, és ha ezt meghaladó értéket képvisel a kincs összessége, akkor annak 50\%-a illeti meg. A malajziai állam fenntartotta magának azt a jogot, hogy bizonyos tárgyakat visszatartson az árveréstől, és állami tulajdonként kezeljen azzal a feltétellel, hogy ezen dolgok értékét a legmagasabb reális áron számítják hozzá az árverésből származó bevételhez. ${ }^{9}$ A szerződés nem tartalmazza, de a malajziai kormány folyamatos felügyeletet gyakorolt a munkálatok felett. ${ }^{10}$

A munkálatok 4 éven keresztül zajlottak, 24000 tárgyat hoztak fel a tengerfenékröl, amelyeket 1995 márciusában az amszterdami Christie's árverésén értékesítettek 2,98 millió amerikai dollár értékben. ${ }^{11} \mathrm{Az}$ MHS 1,2 millió amerikai dollár értékủ díjazást kapott a malajziai kormánytól, amely az aukció nyereségének mindössze $40 \%$-a a $70 \%$ helyett, amely a szerződés szerint járt volna, ráadásul Malajzia 400000 amerikai dollár értékủ kínai eredetű értéktárgyat tartott vissza az árveréstől, amelyböl nem fizetett részesedést a társaságnak. ${ }^{12}$

A szerződés a Kuala Lumpur-i bíróság joghatóságát jelölte ki az esetleges vitarendezés fórumaként, így a társaság először itt próbálta meg érvényesíteni az igényeit. A bíróság azonban elutasította azt, ahogy a fellebbezés nyomán eljáró malajziai legfelsőbb bíróság is. ${ }^{13} \mathrm{Az}$ MHS 2000-ben nemzeti választott bírói fórum elé kívánta vinni az ügyet, ami azonban kudarcba fulladt, 2001-ben elutasították az ügyben való eljárást. ${ }^{14}$

Diana case (Award) 9. pont.

Diana case (Award) 10-11. pont.

Diana case (Award) 12. pont.

Diana case (Award) 13. pont.

Diana case (Award) 14. pont.

Diana case (Award) 15. pont.

14 Diana case (Award) 17. pont. 
Ezek után az MHS 2004. szeptember 30-án a Beruházási Viták Rendezésének Nemzetközi Központjánál kezdeményezett választott bírói eljárást az Egyesült Királyság és Észak-Írország kormánya, illetve Malajzia kormánya által 1988. október 21-én kötött beruházásvédelmi megállapodás megsértésére hivatkozva, arra való tekintettel, hogy az MHS tevékenysége tulajdonképpen beruházás volt. Az ICSID fötitkársága elfogadta a választott bíráskodásra való felkérést, és megküldte a malajziai kormánynak (alperes) az MHS (felperes) keresetét. ${ }^{15} 2007$. május 17-én egyesbírói eljárás keretén belül az ICSID meghozta döntését, amely szerint az MHS tevékenysége nem beruházás, és így az ICSID nem rendelkezik joghatósággal az ügy eldöntésére.

Az ICSID-egyezmény rendelkezései alapján a helyben bejegyzett társaság külföldi részvényesei igényt érvényesíthetnek a felek között kötött szerződés hiányában is. A nemzetközi szokásjog bizonytalanságait elkerülendő a befektetők egyre gyakrabban kötnek a fogadó állammal egyedi beruházási szerződést a beruházásvédelem területén. ${ }^{16} \mathrm{Az}$ ICSID joghatósága azonban csak olyan vitákra terjed ki, melyek közvetlenül beruházások kapcsán keletkeztek és valamilyen jogi kérdést érintenek. $\mathrm{Az}$ Egyezmény azonban nem határozza meg, mit is ért beruházás alatt. ${ }^{17}$

Az eljárás során az egyik legfontosabb kérdés a társaság tevékenységének megítélése volt, vagyis hogy a roncs lokalizálása, illetve az egykori rakomány felszínre hozatala minősíthető-e beruházásnak az ICSID-egyezmény 25. cikk (1) bekezdése értelmében, ${ }^{18}$ és így a BIT (bilateral investment treaty) alkalmazandó-e a jelen ügyben.

\section{Az első felvonás: a felperes tevékenysége nem minősül beruházásnak}

A felperes azzal érvelt, hogy a tevékenysége a Salini-, a Joy Mining-és a L.E.S.I.DIPENTA-ügyekben megállapított elvek fényében beruházásnak minősül, mivel saját pénzügyi, technikai és személyi ráfordítása révén, valamint a mentési múvelet sikertelenségének kockázatát felvállalva teljesítette a szerződésből ráeső kötelezettségeket. Fő jogalapként az Alcoa Minerals-ügyben hozott ítéletet jelölte meg, amely a

15 Diana case (Award) 18-19. pont.

16 L. ICSID Database of Bilateral Investment Treaties. http://icsid.worldbank.org/ICSID/FrontServlet (2012. 07. 03.); SCHIFFNER Imola: A diplomáciai védelem a nemzetközi bíróságok gyakorlatában, különös tekintettel az egyéni jogok érvényesítésére. Acta Juridica et Politica, LXXI (2008) 13 420; Luke Peterson, Eric: Human Rights and Bilateral Investment Treaties. Mapping the Role of Human Rights Law within Investor-State Arbitration. Montreal Rights \& Democracy, (2009) 11.

17 Convention on the settlement of investment disputes between States and nationals of other States. Washington, 18 March 1965, 575 UNTS 160 [a továbbiakban: Washingtoni Konvenció].

18 Washingtoni Konvenció 25. cikk (1) „A Központ joghatósága kiterjed minden olyan beruházásból közvetlenül keletkező jogvitára, amely egyik Szerződő Állam (vagy ezen Szerződő Állam bármely olyan alárendelt szerve vagy ügynöksége, amelyet az a Központnak bejelent) és egy másik Szerződő Állam természetes és jogi személyei között jött létre, amennyiben a vitában álló felek irásban hozzájárulnak a jogvitának a Központ elé terjesztéséhez. Amennyiben a felek hozzájárulásukat adták, azt egyik fél sem vonhatja vissza egyoldalúan." 
tőkeráfordítást a beruházás egy fajtájaként deklarálta. ${ }^{19}$ Ezzel szemben az alperes, a maláj állam szerint az általa és az MHS által kötött szerződésben meghatározott tevékenység célja kizárólag a régészeti célú tanulmányozás volt, és annak jellege nem minősíthető beruházásnak a Salini-ügyben megállapított feltételek szerint, legfőképpen azért, mert nem járult hozzá a maláj állam gazdasági fejlődéséhez. ${ }^{20}$

A legföbb kérdés, hogy milyen tevékenység esik a beruházás fogalma alá. Az ICSID ugyanis kettős tesztet alkalmaz a beruházások megítélésekor: az tudniillik, hogy egy adott tevékenység beruházásnak minősíthető a BIT alapján, még nem jelenti, hogy az ICSID-egyezmény szerint is megfelel a 25. cikk (1) bekezdés szerinti objektív definíciónak. ${ }^{21}$

\subsection{A beruházás fogalma az ICSID gyakorlatában}

A választott bíró az ICSID-egyezmény preambulumának értelmezéséből indult ki, azt a CSOB-ügy alapján úgy értelmezve, hogy a gazdasági fejlődéshez való hozzájárulás kívánatos a beruházások esetén. ${ }^{22} \mathrm{~A}$ következtetését a szerződések jogáról szóló 1969-es Bécsi Egyezmény által előirtakra alapozta, vagyis hogy a szerződéseket jóhiszemüen, kifejezéseinek szövegösszefüggésükben szokásos értelme szerint, valamint tárgya és célja figyelembevételével kell értelmezni. ${ }^{23}$ Ezt követően hét, a befektetés fogalma szempontjából fontos jogeset megállapításait tekintette át.

Az alapügynek számító Salini-ügyben hozott döntés fektette le a beruházás fogalmának alapjait. Eszerint általában akkor minősül egy tevékenység az ICSID-egyezmény 25. cikk (1) bekezdésének hatálya alá tartozónak, ha „...a befektető részéröl hozzájárulást tartalmaz, kockázatvállalást, és bizonyos időintervallumon keresztül folyik. Ezenfelül az egyezmény preambuluma nyomán egyesek a fogadó állam gazdasági fejlődéséhez való hozzájárulását is említik. "24

Kérdés, hogy ezek az elemek milyen kötőerővel bírnak, és milyen az egymáshoz való viszonyuk: konjunktívak, esetleg vagylagosan is elég, ha érvényesülnek. A Saliniügyben használt általában szó arra utal, hogy ezek csak a befektetés jellemző elemei, és nem a kritériumai. ${ }^{25} \mathrm{~A}$ Joy Mining-ügyben az ítélet úgy fogalmazott, hogy egy tevékenységnek meg kell felelnie az ICSID esetjogában foglalt feltételeknek, vagyis

19 Diana case (Award) 12. pont. Az Alcoa-ügy megállapításait lásd: Alcoa Minerals of Jamaica, Inc v Jamaica. ICSID Case No. ARB/74/2. [a továbbiakban Alcoa Minerals].

20 Diana case (Award) 13. pont.

21 Diana case (Award) Joy Mining para. 50.

22 Ceskoslovenska obchodni banka, a.s. v Slovak Republic (Case No. ARB/97/4) [a továbbiakban CSOB-ügy]; Diana case (Award) 64. pont; 66. pont.

23 Vienna Convention on the Law of Treaties, 23 May 1969, 1155 UNTS 331 [a továbbiakban VCLT] 31. cikk (1).

24 The doctrine generally considers that investment infers: contributions, a certain duration of performance of the contract and a participation in the risks of the transaction . . . . In reading the Convention's preamble, one may add the contribution to the economic development of the host State of the investment as an additional condition. Salini Costruttori S.p.A. and Italy strade S.p.A. v Kingdom of Morocco, ICSID Case No. ARB/00/4 [a továbbiakban: Salini-ügy] 52. pont, Diana case (Award) 78. cikk.

25 Diana case (Award) 83. pont. 
ahhoz, hogy beruházásnak lehessen minősíteni, megfelelő időn keresztül szükséges tartania, rendszeres profittal és annak visszaforgatásával szükséges járnia, kockázatvállalást és lényeges kötelezettségvállalást szükséges tartalmaznia, valamint a fogadó állam gazdaságához is ajánlott, hogy hozzájáruljon. Ezek a kritériumok azonban egyedi elbírálás alá esnek az adott ügy speciális körülményeihez igazodva, és összességükben kell őket értelmezni, nem pedig egymástól izolálva. ${ }^{26}$

A L.E.S.I.-DIPENTA-ügy ezzel szemben már három feltételröl szólt, amelyeknek meg kell felelnie az adott tevékenységnek ahhoz, hogy befektetésnek minősítsék. A szerződő félnek bizonyos időn keresztül hozzájárulást kell teljesítenie a fogadó államban, és kockázatot kell vállalnia. Ezenfelül szükséges az is, hogy a tevékenység a fogadó állam gazdasági fejlődését előmozdítsa. ${ }^{27} \mathrm{~A}$ Patrick Mitchell-ügyben ez utóbbi feltétel esetén a bizottság leszögezte, hogy fontos, de nem feltétlen szükséges jellemzője a beruházásnak. ${ }^{28}$

A Bayindir-ügyben eljáró testület úgy fogalmazott, hogy a beruházás fogalma feltételezi az alábbi elemek fennállását: hozzájárulás, időtartam, kockázatvállalás és a gazdasági fejlődéshez való hozzájárulás. A feltételeket azonban összességében kell tekinteni, és figyelembe kell venni az eset körülményeit is. ${ }^{29}$

A Jan de Nul-ítélet a Salini-tesztként emlegetett elemeket iránymutatásoknak (indicatives) nevezi, és az elöbbi esethez hasonlóan összességükben, az eset körülményeinek figyelembevételével kívánja értékelni a tevékenység jellegét. ${ }^{30}$

26 Summarizing the elements that an activity must have in order to qualify as an investment, both the ICSID decisions mentioned above and the commentators theron have indicated that the project in question should have a certain duration, a regularity of profit and return, an element of risk, a substantial commitment and that it should constitute a significant contribution to the host State's economy. To what extent these criteria are met is of course specific to each particular case as they will normally depend on the circumstances of each case. Joy Mining Machinery Limited v Arab Republic of Egypt, ICISD Case No. ARB/03/11. [a továbbiakban: Joy Mining-ügy] 53. pont; Diana case (Award) 84-85. pont.

27 "It would seem consistent with the objective of the Convention that a contract, in order to be considered an investment within the meaning of the provision, should fulfill the following three conditions:a) the contracting party has made contributions in the host country;b) those contributions had a certain duration; and c) they involved some risks for the contributor. On the other hand, it is not necessary that the investment contribute more specifically to the host country's economic development, something that is difficult to ascertain and that is implicitly covered by the other three criteria." Consorzio Groupement L.E.S.I.-DIPENTA v People's Democratic Republic of Algeria. ICSID Case No. ARB/03/08. [a továbbiakban: L.E.S.I.-DIPENTA-ügy] 13. (IV.) pont; Diana case (Award) 89. pont.

${ }^{28}$ "Contribution to the economic development of the host State” characteristic of "investment" is "an essential - although not sufficient -characteristic or unquestionable criterion of the investment." Patrick Mitchell v The Democratic Republic of Congo, ICSID Case No. ARB/99/7. Decision for anullment [a továbbiakban: Patrick Mitchell-ügy] 33. pont; Diana case (Award) 94. pont.

29 (...)held that the notion of investment presupposes the following elements: (a) a contribution, (b) a certain duration over which the project is implemented, (c) sharing of the operational risks, and (d) a contribution to the host State's development, being understood that these elements may be closely interrelated, should be examined in their totality, and will normally depend on the circumstances of each case. Bayindir Insaat Turizm Ticaret Ve Sanayi A.S v Islamic Republic of Pakistan. ICSID Case No. ARB/03/29. [a továbbiakban Bayindir-ügy] 130 pont; Diana case (Award) 99. pont.

30 Jan de Nul N.V. Dredging International N.V. v Arab Republic of Egypt, ICSID Case No. ARB/04/13. Decision on Jurisdiction [a továbbiakba Jan de Nul] 91. pont. 
A befektetés fogalmi elemei az esetjog alapján tehát beazonosíthatóak, az azonban világosan látszik, hogy a jelentőségüket tekintve nincs egységes álláspont, hacsak azt nem tekintjük közös nevezőnek, hogy az adott eset és annak körülményei döntik el, hogy melyiket, mikor és milyen súllyal vesszük figyelembe.

\subsection{Az MHS tevékenységének minősítése}

A rendszeres nyereség elérése és annak visszaforgatása mint a befektetések jellemző vonása a Joy Mining-ügyben jelent meg először, a Salini-tesztnek nem része. A jelen ügyben ez a jelleg nem valósult meg teljességében, ugyanis csak a ráfordítás volt megfigyelhető, amelynek eredményeként egyre több régiséget hoztak a felszínre, az értékesítésükre azonban a munkafolyamat során nem került sor, így visszaforgatott haszonról nem is beszélhetünk. ${ }^{31}$ A felperes hozzájárulása anyagi oldalról, eszközök, know-how és személyzet tekintetében valósult meg. A Diana-ügyben tehát az említett feltétel a klasszikus kereskedelmi zsákmányszerződésre jellemző módon valósult meg. ${ }^{32}$

A szerződés hatályának, a tevékenység végzésének időtartama tekintetében a Salini-ügy ötéves minimumot állapított meg. Minél hosszabb ugyanis a szerződés időbeli hatálya, annál nagyobb a fogadó állam gazdaságára gyakorolt hatása. A Diana-ügyben a szerződést egyszer meghosszabbították, az eredetileg ugyanis csak 18 hónapra szólt, de összesen 4 évet vett igénybe a hajóroncs kincseinek felszínre hozatala. A választott bíró ezt az időintervallumot úgy minősítette, hogy mennyiségileg megfelel a beruházás jellemzőinek, minőségileg azonban nem, de ez önmagában még nem jelenti, hogy a tevékenység ne tartozhatna az ICSID-egyezmény 25. cikk (1) bekezdésének hatálya alá, hiszen a jellemzőket együtt, egymással összefüggésben kell értékelni. ${ }^{33}$

Ami a kockázatvállalást illeti, a zsákmányszerződések fő szabály szerint azt az elvet követik, hogy a zsákmányolónak akkor van haszna, ha talál valamit „,no findsno pay”), és ennek tudatában végzi a tevékenységét. Ez viszont a választott bíró szerint azt is jelenti, hogy az MHS semmivel sem vállalt több kockázatot, mint amenynyit egy átlagos kereskedelmi jellegű zsákmányszerződés egyébként is tartalmaz, ezért mennyiségileg elfogadhatónak ítélte meg a felperes kockázatvállalását, amely azonban minőségét tekintve nem elegendő ahhoz, hogy azt minőségileg is beruházásnak megfelelő kockázatként fogadja el. ${ }^{34}$

A legellentmondásosabb az összes jellemző közül a tevékenységnek a fogadó állam gazdaságára gyakorolt hatásának a megítélése. A Salini-ügyben nem minősítették szükségszerúnek, noha a kívánalmat megfogalmazták, a L.E.S.I.-DIPENTAügyben pedig nem is vizsgálták külön a meglétét, mivel úgy vélték, hogy a többi feltételben burkoltan benne van a gazdasági hatásra vonatkozó információ is. Ezzel

31 Diana case (Award) 109. pont.

32 Uo. 109. pont.

33 Diana case (Award) 110-111. pont.

34 Uo. 112. pont. 
ellentétben a Joy Mining-ügyben már úgy fogalmaztak, hogy a tevékenységnek gazdaságerősítő hatása kell hogy legyen. Érdekes módon a Bayindir-ügyben a Joy Miningügyet idézve ugyanez a jellemző már nem feltétlen szükséges, hanem kívánatos elemként jelenik meg. A Jan de Nul-esetben a Salini-, a Bayindir- és a L.E.S.I.DIPENTA-ügyet idézve a beruházás szignifikáns elemének minősítették a gazdaságfejlesztéshez való hozzájárulást, ahogy a CSOB-ügyben is. ${ }^{35} \mathrm{~A}$ Patrick Mitchell-ügyben viszont úgy fogalmaztak, hogy a gazdaságra gyakorolt hatás lényeges, de nem elegendő, mérhető vagy sikert jelentő feltétele a beruházás fogalmának. ${ }^{36}$ Ezzel szemben a PSEG-ügyben az eljáró választott bírói bizottság lényegesnek tekintette azt, hogy a beruházás jelentősen járuljon hozzá a fogadó állam gazdaságának fejlödéséhez. ${ }^{37}$

A Diana-ügyben is jelentős problémát okozott annak megítélése, hogy a maláj kormány és az MHS által kötött szerződés alapján végzett tevékenység vajon megvalósítja-e a gazdasági fejlödéshez köthető jellemzőt, és az eredmény mennyiben és milyen irányban befolyásolhatja a beruházásként minősítést. A felperes arra hivatkozott, hogy több mint 40 helyi, maláj lakost alkalmaztak a mütárgyak tisztítása, katalogizálása, fotózása végett, és ezáltal a zsákmányolás iparágához mérten jelentősen hozzájárultak a gazdasághoz. Ezt a tényt a választott bíróság is elismerte, de úgy vélte, hogy a felek közötti szerződés inkább szolgáltatási, mintsem az ICSIDegyezmény 25 cikk (1) bekezdése értelme szerinti beruházási szerződés, így a felperes által végzett, a roncs lokalizálására és a rakományának kimentésére irányuló tevékenységét nem minősítette beruházásnak. A szerződés eredményeként inkább kulturális, archeológiai előny keletkezett, mintsem gazdaságban mérhető hatás. ${ }^{38}$

A döntés alapján az ICSID nem rendelkezik joghatósággal a felek közötti vitás kérdés eldöntésére, a perköltséget pedig megosztotta közöttük. ${ }^{39}$

\section{A második felvonás: a felperes tevékenysége beruházásnak minősül}

Az MHS a rendelkezésre álló határidőn belül ${ }^{40} 2007$. szeptember 7 -én az ICSIDegyezmény 52 . cikk (1) bekezdés $b$ ) pontja alapján ${ }^{41}$ kérelmezte az ítélet hatályon kívül helyezését. 2007. október 30-án került sor a háromtagú ad hoc bizottság kije-

35 CSOB-ügy 64. pont.

36 Patrick Mitchell-ügy 33. pont.

37 PSEG Global Inc and Konya Ilgin Elektrik Üretim ve Ticaret Limited Sirketi v Republic of Turkey, ICSID Case No. ARB/02/5. [PSEG] 85. pont; Diana-case (Award) 113-119. pont.

38 Diana case (Award) 132-138., 146. pont.

39 Diana case (Award) 151. pont. A döntés elemzését lásd: AndREeVA, Yulia: Salvaging or Sinking the Investment? MHS v. Malaysia Revisited. The Law and Practice of International Courts and Tribunals 2008. 7/2. sz. 161-175. o.

40 Washingtoni Konvenció 52. cikk (2): „A kérelmet az ítélet meghozatalának napjától számított 120 napon belül kell benyújtani, kivéve, ha a hatályon kívül helyezést megvesztegetésre hivatkozással kérték, az ilyen kérelmet a megvesztegetés felfedezésétől számított 120 napon belül, de legkésőbb az ítélet hozatalának napjától számított három éven belül kell előterjeszteni."

41 Washingtoni Konvenció 52. cikk (1): „Bármelyik fél a főtitkárhoz intézett írásbeli kérelem útján kérheti az ítélet hatályon kívül helyezését az alábbi indokok alapján: (...) b) a bíróság nyilvánvalóan túllépte hatáskörét." 
lölésére, amely részletesen elemezte a beruházás fogalmát, és az ítélettel szemben a felperes álláspontja mellett tette le a voksát.

A bizottság az ICSID-egyezmény és a brit-maláj BIT értelmezéséből indult ki, és leszögezte, hogy az 1969-es Bécsi Egyezmény szabályai expressis verbis nem alkalmazhatóak a jogvitában, ugyanis annak hatálya csak azokra a szerződésekre terjed ki, amelyeket a hatálybalépése után kötöttek. ${ }^{42}$ Így nemcsak az 1965-ös Washingtoni Konvencióra, hanem az 1981-es BIT-re vonatkozóan is a szerződések értelmezésére vonatkozó szokásjog - amelyet gyakorlatilag a Bécsi Egyezmény kodifikált - alkalmazandó, hiszen Malajzia csak 1994-ben vált az utóbbi egyezmény részesévé. ${ }^{43}$

Az ICSID-egyezmény célja a tervezetek és elökészítő dokumentumok alapján egyértelmüen a 25. cikk (1) bekezdés tág értelmezése, ezért is nem határozták meg a beruházás fogalmát, és az egyezmény megszövegezésekor ezért vetettek el minden részletszabályozás iránti kezdeményezést. Elvetették a beruházás értékének számszerüsítését, és az időintervallum meghatározását (ami egyébként megegyezett a későbbi Salini-ügyben meghatározott öt évvel). A travaux préparatoire alapján az ICSID joghatóságát a felek akaratának rendelték alá, vagyis a beruházás fogalmának meghatározásakor a felek megegyezése a döntő, az egyetlen kritérium, hogy jogvitáról legyen szó. ${ }^{44} \mathrm{~A}$ bizottság azzal érvelt, hogy a közel 3000 beruházásvédelmi szerződés is jellemzően tágan értelmezi a beruházás fogalmát. ${ }^{45}$ Kihangsúlyozta továbbá, hogy az ICSID joggyakorlatában előforduló fogalmi elemek csak a beruházás jellemzői, és nem a minősítés feltételei. ${ }^{46}$ Emiatt hatályon kívül helyezte az egyesbírói eljárás során, 2007. május 17-én született választott bírósági ítéletet, és elismerte a felperes tevékenységét mint beruházást.

\section{A jövő kérdései}

A hatályon kívül helyező döntés során a három választott bíróból egy, Shahabuddeen bíró kifejezetten ellenezte a 2007-es ítélettel szembeni álláspontot, és a gazdasági növekedés fontossága mellett tette le a voksát. A döntéshozatal eredményét titáni küzdelemként jellemezte a két pártra szakadt bírák között: azok között, akik a beruházás fogalmát a felek szándékától tették függővé, és azok között, akik az ICSID elvei fényében a fogadó állam gazdasági növekedésében látják annak lényegétt. ${ }^{47} \mathrm{Az}$ annulláló határozat szükszavúságát a jogirodalmi álláspontok sem bővítik: valószínü, hogy a Malaysian Historical Salvors bízott abban, hogy minden, az ICSID joghatósága alá eső beruházás védelemben részesül, míg Malajzia abban a hitben lehetett, hogy a testület csak a gazdasági fejlődéssel járó tevékenységeket minősíti a jogha-

42 VCLT 4. cikk.

43 Diana case (Annulment) 56. pont.

44 Uo. 59-72. pont.

45 Uo. 73. pont.

46 Uo. 79. pont.

47 Dissenting Opinion of Judge Mohamed Shahabuddeen (attached to the Decision on the Application for Annulment) (April 16, 2009) 62. pont. 
tósága alá tartozó beruházásként, mindenesetre választ a kérdésre azóta sem kaptunk..$^{48}$ Első benyomásként az ügy ugyanis olyan képet fest, ami szerint a klasszikus „no finds-no pay” jellegủ mentések nem minősülhetnek az ICSID értelmezése szerinti beruházásnak..$^{49}$ Ezen a szigoron enyhít a tény, hogy ezt a döntést annullálták, és az azt megelőző napon egy másik ügyben is a liberálisabb beruházásfogalmi felfogást tükröző döntés született, amely kiemelte, hogy a gazdasági növekedéshez való hozzájárulás mint fogalmi elem eleve vélelmezendő, hiszen nyilvánvaló, hogy anélkül meg sem kötnék a BIT-et. ${ }^{50}$

A döntés két jogterület számára jelent alapkövet. Egyrészt a nemzetközi beruházásvédelem területén a konkrét ügyben való döntéstöl függetlenül a beruházás fogalmi elemeire vonatkozóan jelent teljes, a megelőző ICSID-döntésekre kiterjedő áttekintést és szintézist, amely a joggyakorlat számára alapvető iránymutatás. ${ }^{51}$

Az ügy kifejezetten elörelépést jelent a hajóroncsok esetén a mentésre vonatkozó anyagi jog bővülése terén. Habár az ICSID döntése alapvető jogforrásként nem értékelhetö, ugyanakkor a mentési jog kaotikus szabályai között új irányt jelent a mentést végzők tevékenységének ilyen jellegủ védelme, illetve vitarendezési fórumként - természetesen az ehhez szükséges egyéb feltételek megléte esetén - az ICSID.

\section{Abstract}

In 2007 the ICSID concluded that MHS's contract with Malaysia to undertake complex salvage operations considered investment even if it had not significantly contributed to Malaysia's economic development thus failed to fall within the scope of the former interpretation of the notion of investment. This decision is significant in the sphere of international investment law as it synthesizes the former practice of the ICSID concerning the definition and conceptual elements of the notion of 'investment'. Besides, the Diana case serves for the enlargement of salvage law; however it cannot be defined as a classical source of law. It gives a new way to legal protection for salvage activity thus it contributes to the orientation in the chaotic mass of mainly customary rules related to shipwreck salvaging.

48 SornarajaH, Muthucumaraswamy: The International Law on Foreign Investment. Cambridge, Cambridge University Press (2010) 312-313. o.

49 Given, John P.: Malaysia Historical Salvors Sdn., Bhd. v. Malaysia: An End to the Liberal Definition of Investment in ICSID Arbitrations. Loyola of Los Angeles International and Comparative Law Review, Vol. 31. 2009, 498.

50 Phoenix Action, Ltd. V. Czech Republic (ICSID Case No. ARB/06/5.) Award, April 15, 2009, 85. pont; Given i. m., 500 .

51 Lásd: Given i. m., 467-500. 